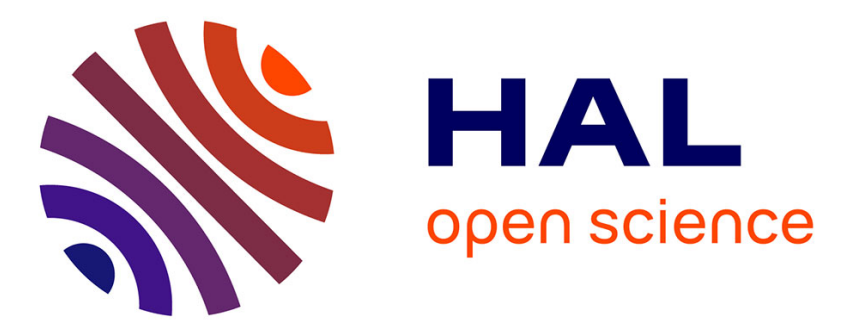

\title{
Changes in deep water hydrology during the Last Deglaciation
}

Laurent Labeyrie, Claire Waelbroeck, Elsa Cortijo, Elisabeth Michel, Jean-Claude Duplessy

\section{- To cite this version:}

Laurent Labeyrie, Claire Waelbroeck, Elsa Cortijo, Elisabeth Michel, Jean-Claude Duplessy. Changes in deep water hydrology during the Last Deglaciation. Comptes Rendus Géoscience, 2005, 337 (10-11), pp.919-927. 10.1016/j.crte.2005.05.010 . hal-02913485

\section{HAL Id: hal-02913485 \\ https://hal.science/hal-02913485}

Submitted on 9 Oct 2020

HAL is a multi-disciplinary open access archive for the deposit and dissemination of scientific research documents, whether they are published or not. The documents may come from teaching and research institutions in France or abroad, or from public or private research centers.
L'archive ouverte pluridisciplinaire HAL, est destinée au dépôt et à la diffusion de documents scientifiques de niveau recherche, publiés ou non, émanant des établissements d'enseignement et de recherche français ou étrangers, des laboratoires publics ou privés. 


\title{
Changes in deep water hydrology during the Last Deglaciation
}

\author{
Laurent Labeyrie*, Claire Waelbroeck, Elsa Cortijo, Elisabeth Michel, \\ Jean-Claude Duplessy
}

\begin{abstract}
Institut Universitaire de France, Université Versaille St-Quentin, Laboratoire des sciences du climat et de l'environnement,
\end{abstract} UM CEA-CNRS, domaine du CNRS, 91198 Gif-sur-Yvette cedex, France

Accepted after revision 3 May 2005

Available online 11 July 2005

Written on invitation of the Editorial Board

\begin{abstract}
Changes in benthic foraminifera $\delta^{18} \mathrm{O}$ and $\delta^{13} \mathrm{C}$ have been followed over the last deglaciation period in seven sediment cores from different water depths in the North Atlantic, Indian and Pacific Ocean. The two periods of most rapid $\delta^{18} \mathrm{O}$ changes, at about 17 and $12 \mathrm{ka}$, are recorded in all intermediate water cores simultaneously with the penetration of brines formed along the polar ice shelves, exhibiting low $\delta^{18} \mathrm{O}$ and $\delta^{13} \mathrm{C}$ signatures. At the opposite, exchanges between intermediate and deep waters were slow. But here again, Atlantic and Pacific deep waters were affected simultaneously. These results would give a major role to convection around Antarctica a major role in deep circulation during these periods. To cite this article: L. Labeyrie et al., C. R. Geoscience 337 (2005).

() 2005 Published by Elsevier SAS on behalf of Académie des sciences.
\end{abstract}

\section{Résumé}

Changements de l'hydrologie profonde pendant la dernière déglaciation. Les changements de $\delta^{18} \mathrm{O}$ et $\delta^{13} \mathrm{C}$ des foraminifères benthiques lors de la dernière déglaciation ont été mesurés dans sept carottes sédimentaires à différentes profondeurs dans les océans Atlantique nord, Indien et Pacifique. Deux périodes d'évolution rapide du $\delta^{18} \mathrm{O}$, autour de $17 \mathrm{et} 12 \mathrm{ka}$, sont associées à la pénétration de saumures de faible $\delta^{18} \mathrm{O}$ et $\delta^{13} \mathrm{C}$ dans les eaux intermédiaires atlantiques depuis les zones de convection de haute latitude. Une circulation active d'eau intermédiaire peu ventilée était maintenue au cours de chaque événement, et les différents océans ont répondu en phase, peut-être grâce à des échanges péri-antarctiques actifs. La pénétration du signal d'anomalie isotopique dans les eaux profondes était en revanche plus lente, mais, comme pour les eaux intermédiaires, sans retard entre les océans Atlantique et Pacifique. Pour citer cet article $:$ L. Labeyrie et al., C. R. Geoscience 337 (2005). () 2005 Published by Elsevier SAS on behalf of Académie des sciences.

Keywords: Palaeoceanography; Palaeoclimatology; Heinrich events; Benthic foraminifera; ${ }^{18} \mathrm{O} /{ }^{16} \mathrm{O}$ ratio; ${ }^{13} \mathrm{C} /{ }^{12} \mathrm{C}$ ratio; Atlantic ocean;

Thermohaline circulation

Mots-clés : Paléoceanographie; Paléoclimatologie ; Foraminifères benthiques ; Rapport ${ }^{18} \mathrm{O} /{ }^{16} \mathrm{O}$; Rapport ${ }^{13} \mathrm{C} /{ }^{12} \mathrm{C}$; Océan Atlantique ;

Événement de Heinrich; Circulation thermohaline

\footnotetext{
* Corresponding author.

E-mail address: Laurent.Labeyrie@1sce.cnrs-gif.fr (L. Labeyrie).
} 


\section{Version française abrégée}

Malgré le nombre d'études ayant couvert la période de la dernière déglaciation, la succession des événements ayant accompagné la disparition des grandes calottes de la Laurentide et de la Fenno-Scandie, avec les alternances froides et chaudes brutales du Dryas ancien, Bølling-Allerød et Dryas récent, est encore très mal comprise. De nombreuses données font apparaitre un couplage étroit entre changements de la circulation profonde, hydrologie de surface et température de l'air aux hautes latitudes nord, mais la nature de ce couplage, ainsi que l'existence même d'instabilités thermohalines ayant pu entraîner les coups de froid des périodes Dryas ancien et Dryas récent [4], font encore l'objet d'intenses discussions. Les événements de Heinrich, périodes de débâcles rapides de fractions importantes de la calotte Laurentide paraissent à cet égard des cas d'école, car ils associent l'arrivée d'une quantité significative d'eau douce en surface aux hautes latitudes nord [2,3], un refroidissement important [5], et un ralentissement (ou même un arrêt) de la circulation profonde [12,18-20,29,39]. Mais il n'en est pas de même pour le refroidissement du Dryas récent, pour lequel on n'a jamais retrouvé d'indice d'arrivée massive d'eau douce en surface, ni de preuve d'un arrêt de la circulation thermohaline. Par ailleurs, la période de réchauffement maximum des hautes latitudes nord (14-15 ka) est aussi celle de fonte la plus rapide des calottes et de montée du niveau de la mer.

La présente étude vise à améliorer l'interprétation des changements de la composition isotopique $\delta^{18} \mathrm{O}$ et $\delta^{13} \mathrm{C}$ des foraminifères benthiques lors de la déglaciation, en termes de changements des caractéristiques de la circulation profonde. Les foraminifères benthiques de sept carottes sédimentaires prélevées à différentes profondeurs de l'Atlantique nord, de l'océan Indien et de l'océan Pacifique (Tableau 1) ont été étudiés. Toutes les carottes ont été datées de façon précise. Celles de basse latitude ont été datées directement par le ${ }^{14} \mathrm{C}$ des foraminifères planctoniques, et transformation des âges radiocarbone en âges calendaires (cal ka) grâce au programme Calib [38], après correction d'un âge réservoir de 400 ans. Pour les carottes de plus haute latitude, il faut prendre en compte l'augmentation des âges de ventilation des eaux de surface, liée à des échanges plus faibles avec l'atmosphère. La cor- rélation avec les séries paléoclimatiques du Groenland permet d'affiner ce paramètre [14,34,40]. Les séries sont reportées en fonction de l'âge calendaire (Fig. 1A pour le $\delta^{18} \mathrm{O}$ et Fig. 1B pour le $\delta^{13} \mathrm{C}$ ).

La dérivée des signaux isotopiques par rapport au temps isole chaque événement correspondant à une période de changement rapide ainsi que son intensité. Les résultats sont reportés sur la Fig. 2A pour le $\partial \delta^{18} \mathrm{O} / \partial t$ et sur la Fig. 2B pour le $\partial \delta^{13} \mathrm{C} / \partial t$. Deux périodes de changement rapide du $\delta^{18} \mathrm{O}$ sont clairement apparentes autour de 17 et $12 \mathrm{ka}$ (les épisodes froids $\mathrm{H} 1$ et Dryas récent). Ces deux événements s'accompagnent de baisses significatives du $\delta^{13} \mathrm{C}$, mais ils ne sont néanmoins pas directement comparables. En effet, la circulation profonde dans la période précédant l'événement lié à H1 (le dernier maximum glaciaire) était très différente de la circulation profonde dans la période précédant le Dryas récent (l'interstade chaud du Bølling-Allerød). Le $\delta^{13} \mathrm{C}$ des eaux au-dessus de $2000 \mathrm{~m}$ était élevé pendant la période glaciaire, traduisant une ventilation et un renouvellement important des eaux intermédiaires, alors que les eaux plus profondes étaient peu ventilées $[11,15]$. Pendant la période du Bølling-Allerød, la circulation océanique et la ventilation des eaux intermédiaires et profondes ressemblaient plus à celles de la période actuelle [30]. Les sauts isotopiques ont été associés à deux étapes successives de réorganisation de la circulation profonde ayant conduit à la circulation actuelle (Fig. 1B).

Des travaux récents [35] montrent que des changements significatifs de température de l'eau profonde coïncident avec les changements de $\delta^{18} \mathrm{O}$, mais avec un effet opposé : au début des événements, les températures diminuent, et tendent donc à augmenter le $\delta^{18} \mathrm{O}$ des foraminifères. À la fin de chaque événement, on trouve l'effet inverse : un réchauffement des eaux de fond tend à limiter l'augmentation du $\delta^{18} \mathrm{O}$ des foraminifères. La baisse du $\delta^{18} \mathrm{O}$ des foraminifères pendant chacun des sauts isotopiques fait donc sous-estimer la baisse réelle du $\delta^{18} \mathrm{O}$ de l'eau. L'anomalie isotopique observée est, par ailleurs, trop grande pour correspondre à une fonte des calottes de glace telle que le montrent les changements du niveau de la mer (Figs. 1 et 2). Nous les expliquons par l'injection en profondeur d'eau lors de la formation de saumures [7,39], seul mécanisme de formation de l'eau profonde lors de ces périodes de baisse importante de la salinité de surface aux hautes latitudes. Nos ré- 
sultats montrent que l'eau ainsi marquée pendant $\mathrm{H} 1$ envahit très rapidement les couches intermédiaires des différents océans, mais beaucoup plus lentement les couches profondes. Le renouvellement des eaux intermédiaires reste donc important, malgré la baisse de la ventilation, sans doute associée à la disparition de la convection profonde dans les zones libres de glace. Les eaux profondes en revanche, tant en Atlantique que dans le Pacifique, ne se modifient que progressivement, 1,5 ka plus tard. Ce résultat confirme donc l'isolement des eaux profondes. Après une reprise de la convection profonde lors de la période du BøllingAllerød, le saut isotopique lié au Dryas récent marque le retour à un régime de convection limité à la formation de saumures. Les eaux profondes de l'Atlantique nord (carotte CH69-K09, $4100 \mathrm{~m}$ ), comme en ce qui concerne l'événement associé à $\mathrm{H} 1$, ne reçoivent le signal que 1,5 ka après. En revanche, la transmission du signal vers $3000 \mathrm{~m}$ pourrait être plus complexe car, aussi bien dans l'Atlantique que le Pacifique, on ne distingue plus la présence du saut caractéristique. Il pourrait même y avoir décomposition en deux événements successifs, l'un en phase avec celui des eaux intermédiaires, l'autre plus tardif, en phase avec les eaux profondes (Fig. 2A). Par ailleurs, aucune source significative d'eau de fonte n'a été observée pendant cette période (le Dryas récent) aux hautes latitudes nord. Cette période est donc loin d'avoir délivré tous ses secrets.

\section{Introduction}

Understanding the links between changes in climate and ocean circulation is a major challenge in palaeoclimatology. The last deglaciation period is especially interesting in that respect, with oscillations between warm (Bølling-Allerød) and cold events (Younger Dryas), although summer insolation was at its maximum in the Northern Hemisphere and ice sheets, which accumulated during the Last Glacial period, were rapidly disappearing.

Stommel [37] was among the first to consider potential instabilities in the density driven deepocean circulation (the thermohaline circulation, THC), when changes in high-latitude salinity affect deepwater convection. Broecker [4] emphasized the consequences of THC reduction as a cause for northern hemisphere cooling, as observed during the Younger Dryas (YD). Other cold periods have been described since these early works, and linked to Heinrich Events $(\mathrm{H \#})$, periods of drastic iceberg surges and meltwater input to the northern Atlantic that occurred every 5 to $10 \mathrm{ka}$ during the last glaciation, and resulted in rapid drops in sea-surface temperature and in atmospheric cooling $[2,3,5,19,20]$. Decreases in deep water ventilation are also observed during $\mathrm{H \#}[18,33,39]$. Numerous climate model simulations effectively link decrease in high-latitude surface salinity and THC to drops in Northern Hemisphere temperature [27,29,36]. H1 (about 17.5 to 16 cal ka) occurred at the beginning of the last deglaciation. It has been related to the last large amplitude surge of the Laurentide ice sheet and resulted in both surface water cooling around $45^{\circ} \mathrm{N}$ $[1,18]$ and reduction in deep water ventilation $[18,39]$. However, northeastern Atlantic did not cool significantly during that period [6].

The link between ice sheet melting, THC, and climate is unclear during the last deglaciation, as no direct link can be observed between the global record of ice sheet melting derived from that of sea level [21], records of meltwater input into the North Atlantic Ocean [24], and changes in THC $[16,18]$. The period of maximum melting of the Laurentide ice sheet and faster global sea level rise (meltwater event $1 \mathrm{~A}$, about 14 cal ka) coincides with vigorous THC and warm conditions over the Northern Hemisphere.

In this paper, we analyse the link between climate and THC by comparing changes in oxygen and carbon isotopic composition (expressed as $\delta^{18} \mathrm{O}$ and $\delta^{13} \mathrm{C}$ ) of benthic foraminifera in seven cores collected at different depths in the North Atlantic, Indian and Pacific oceans, which provide high-resolution, welldated records of the last deglaciation (Table 1).

\section{Material and methods}

Time scales are based on AMS ${ }^{14} \mathrm{C}$ dating of hand picked fossil planktic foraminifera. ${ }^{14} \mathrm{C}$ ages were converted in calendar ages using the software Calib 4.3 [38], and are given here as cal ka. Data may be obtained from the authors. Ages are calculated using the standard 0.4-ka reservoir age, except for cores CH69K09 and NA87-22, which have been corrected for large changes in reservoir age of polar water during 
Table 1

Sediment cores used for this study

Tableau 1

Carottes de sédiment étudiées

\begin{tabular}{|c|c|c|c|c|c|}
\hline \# in Figures & core \# & Latitude Longitude & Water depth (m) & Localisation & References \\
\hline 1 & CHO288-54 & $17^{\circ} 25.6^{\prime} \mathrm{N}, 77^{\circ} 39.4^{\prime} \mathrm{W}$ & 1020 & Caribbean Sea & this work \\
\hline 2 & MD98-2165 & $9^{\circ} 38^{\prime} 96 \mathrm{~S}, 118^{\circ} 20^{\prime} 31 \mathrm{E}$ & 2100 & Indian Ocean & {$[22,41]$} \\
\hline 3 & MD95-2037 & $37^{\circ} 05.2^{\prime} \mathrm{N}, 32^{\circ} 01.9^{\prime} \mathrm{W}$ & 2159 & North Atlantic & this work \\
\hline 4 & $\mathrm{Na} 87-22$ & $55^{\circ} 29^{\prime} 8 \mathrm{~N}, 14^{\circ} 41^{\prime} 7 \mathrm{~W}$ & 2161 & North Atlantic & {$[40]$} \\
\hline 5 & MD95-2042 & $37^{\circ} 48^{\prime} \mathrm{N}, 10^{\circ} 10^{\prime} \mathrm{W}$ & 3146 & North Atlantic & {$[34]$} \\
\hline 6 & CH 69-K09 & $41^{\circ} 45^{\prime} 4 \mathrm{~N}, 47^{\circ} 21^{\prime} \mathrm{W}$ & 4100 & North Atlantic & {$[40]$} \\
\hline 7 & TRI163-31 & $3^{\circ} 37^{\prime} \mathrm{S}, 83^{\circ} 58^{\prime} \mathrm{W}$ & 3210 & Pacific Ocean & {$[34]$} \\
\hline
\end{tabular}

the deglaciation by correlation with the Greenland ice record between 15 and $10 \mathrm{cal} \mathrm{ka} \mathrm{[40].} \mathrm{We} \mathrm{have} \mathrm{taken}$ a mean reservoir effect of $0.8 \mathrm{ka}$ for all dates prior to $15 \mathrm{ka}$ cal ka. The chronology of core MD95-2042 obtained by correlation with the Greenland $\delta^{18} \mathrm{O}$ ice record [14], after checking that the ages were coherent with AMS dates from companion cores [34].

Benthic foraminiferal $\delta^{18} \mathrm{O}$ and $\delta^{13} \mathrm{C}$ records were obtained at Gif with an external reproducibility at one sigma of $0.05 \%$ for $\delta^{18} \mathrm{O}$ and $0.03 \%$ for $\delta^{13} \mathrm{C}$. The isotopic data is reported versus PDB following [26]. $\delta^{18} \mathrm{O}$ values are reported on the corrected Uvigerina scale $\left(+0.64 \%\right.$ for $C$. wuellerstorfi), and $\delta^{13} \mathrm{C}$ values are reported only for $C$. wuellerstorfi (except for $\mathrm{Pa}$ cific core TR 133-31, where Uvigerina peregrina $\delta^{13} \mathrm{C}$ are reported [32,34]). We did not consider the $\delta^{13} \mathrm{C}$ record of core MD95-2042, as the available resolution for $C$. wuellerstorfi is insufficient for our purpose, but we kept the $\delta^{18} \mathrm{O}$ record to allow comparison of our study with [34].

Fig. 1 presents the different benthic foraminifera $\delta^{18} \mathrm{O}$ and $\delta^{13} \mathrm{C}$ records vs time. Benthic foraminifera $\delta^{18} \mathrm{O}$ values depend on both $\delta^{18} \mathrm{O}$ and temperature of seawater during the period of shell growth. Seawater $\delta^{18} \mathrm{O}$ during the deglaciation depends on the integrated amount of meltwater having reached the ocean (monitored by the sea-level curve), and local $\delta^{18} \mathrm{O}$ anomalies that result from changes in salinity and/or injection of glacial brine water of low $\delta^{18} \mathrm{O}[7,8]$. The benthic foraminifera $\delta^{13} \mathrm{C}$ record integrates several parameters: the $\delta^{13} \mathrm{C}$ value of the sinking water in regions of deep water formation, the amount of mineralization of organic matter depleted in ${ }^{13} \mathrm{C}$ within the water mass, and mixing between deep water masses with different $\delta^{13} \mathrm{C}$ values. In addition, growth or decay of the continental biosphere will affect the oceanic carbon budget and result in $\delta^{13} \mathrm{C}$ variation in the whole ocean, but this is a slow process we will not consider here.

We focused our attention on the timing of the main transitions recorded in the different deglacial series. As these series integrate singular events, with their own dynamics, each major event has been individualized by taking the first time derivative of the isotopic records, calculated following the parameterisation scheme of [31], with a quadratic function of $1.3 \mathrm{ka}$ half-width, after interpolation at $0.2 \mathrm{ka}$ (sampling resolution is in the range 0.15 to $0.3 \mathrm{ka}$, except for a few intervals where it increases to about $0.5 \mathrm{ka}$ ). These reconstructions are reliable only for portions of records generated with more than 4 to 5 data point per ka (Fig. 1). Results of this treatment are reported in Fig. 2.

\section{Discussion of the derivative signals}

The general trends of the benthic foraminifera $\delta^{18} \mathrm{O}$ deglacial records are well known, with two successive steps following respectively the Last Glacial Maximum and the YD periods. It is clearly visible in the present set of cores that these steps are not in phase.

During the Last Glacial Maximum, a strong benthic front separated a deep reservoir with low $\delta^{13} \mathrm{C}$ values $(\leqslant 0 \%)$ from a shallower reservoir, above 2000 $\mathrm{m}$, with high $\delta^{13} \mathrm{C}$ values $(\sim+1 \%)[11,15]$. By contrast with the glacial pattern, in the modern ocean, most of the $\delta^{13} \mathrm{C}$ gradient occurs between the wellventilated Atlantic Ocean and the Indian and Pacific 


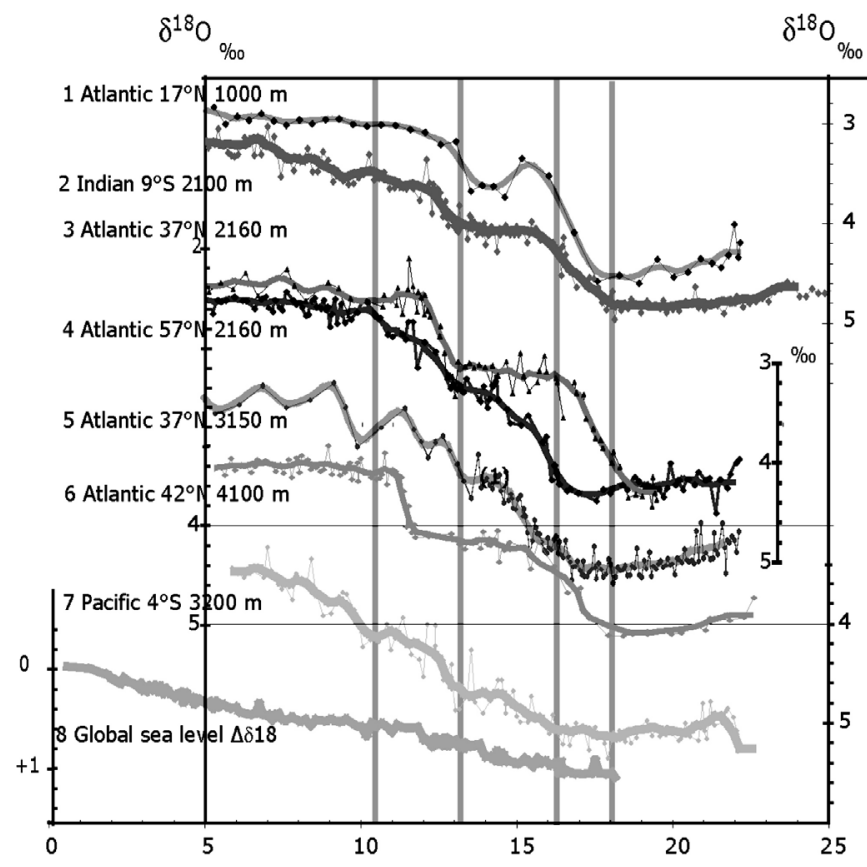

A

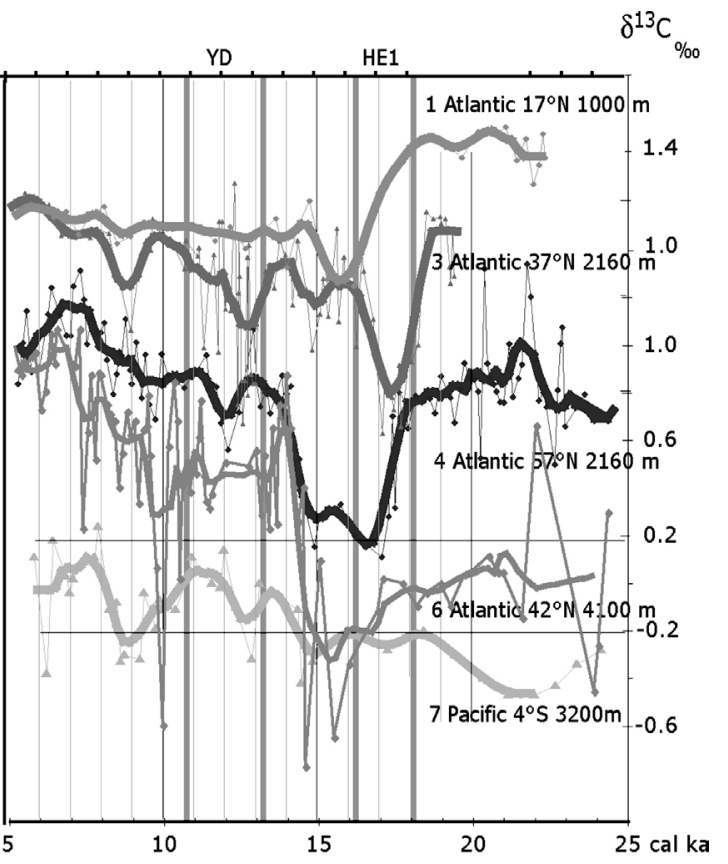

B

Fig. 1. (A) Benthic foraminifera $\delta^{18} \mathrm{O}$ versus age (cal ka) and running mean (Fourier transform, 1-ka-width window [28] for the different cores. The reference number for each core refers to Table 1. (B) Same for benthic foraminifera $\delta^{13} \mathrm{C}$.

Fig. 1. (A) $\delta^{18} \mathrm{O}$ des foraminifères benthiques en fonction de l'âge (cal ka) et moyenne glissante (transformée de Fourier, fenêtre 1 ka [28]) pour les différentes carottes. Le numéro de référence pour chaque carotte correspond à celui donné dans le Tableau 1 . (B) Idem pour le $\delta^{13} \mathrm{C}$ des foraminifères benthiques.

oceans, which have no local source of ventilated deep water [17]. Fig. 1B shows that, as for $\delta^{18} \mathrm{O}$, the transition to the modern pattern during the deglaciation developed in at least two steps, which were not in phase in different cores.

Two to three events may be identified in the $\partial \delta^{18} \mathrm{O} / \partial t$ (Fig. 2A) and $\partial \delta^{13} \mathrm{C} / \partial t$ (Fig. 2B) records. We will focus on the two largest, which are simpler to interpret.

The first $\partial \delta^{18} \mathrm{O} / \partial t$ event initiates the deglaciation, at about $17 \mathrm{cal} \mathrm{ka}( \pm 0.5 \mathrm{cal} \mathrm{ka}$, taking the dating uncertainties in account) in all shallow and intermediate waters records between 1000 and $2200 \mathrm{~m}$ in the Atlantic and Indian Oceans. This event is clearly identified in North Atlantic surface water records as the meltwater event associated with Heinrich event H1 [8, $18,39]$. It corresponds to a synchronous large amplitude negative shift of the benthic foraminifera $\delta^{18} \mathrm{O}$ $(\sim 1 \%$ over $1.5 \mathrm{ka})$ in intermediate water cores, be- tween 1000 and $2200 \mathrm{~m}$ in the Atlantic and Indian Oceans. In contrast, deep waters from the Atlantic and Pacific oceans exhibit a progressive shift, with the peak of the input signal arriving $\sim 1$ to $1.5 \mathrm{ka}$ after the signal observed in intermediate waters. North Atlantic core MD95-2042, at $3150 \mathrm{~m}$, appears to show a later response than the deeper core CH69-K09, but resolution of this last core is low during that period (about $1 \mathrm{ka}$ ), and our age model may overestimate the age of this transition (when compared to [40]).

The second significant $\partial \delta^{18} \mathrm{O} / \partial t$ event, at about 13 cal ka, marks the beginning of the YD. Both events coincide with drastic Northern Hemisphere cooling. They also indicate the same general trend in their transfer to intermediate and deep waters. As for the first event, the records around $3000 \mathrm{~m}$ are similar in the Pacific and Atlantic oceans.

These two last records show three oscillations. The first, already discussed, corresponds to the delayed re- 


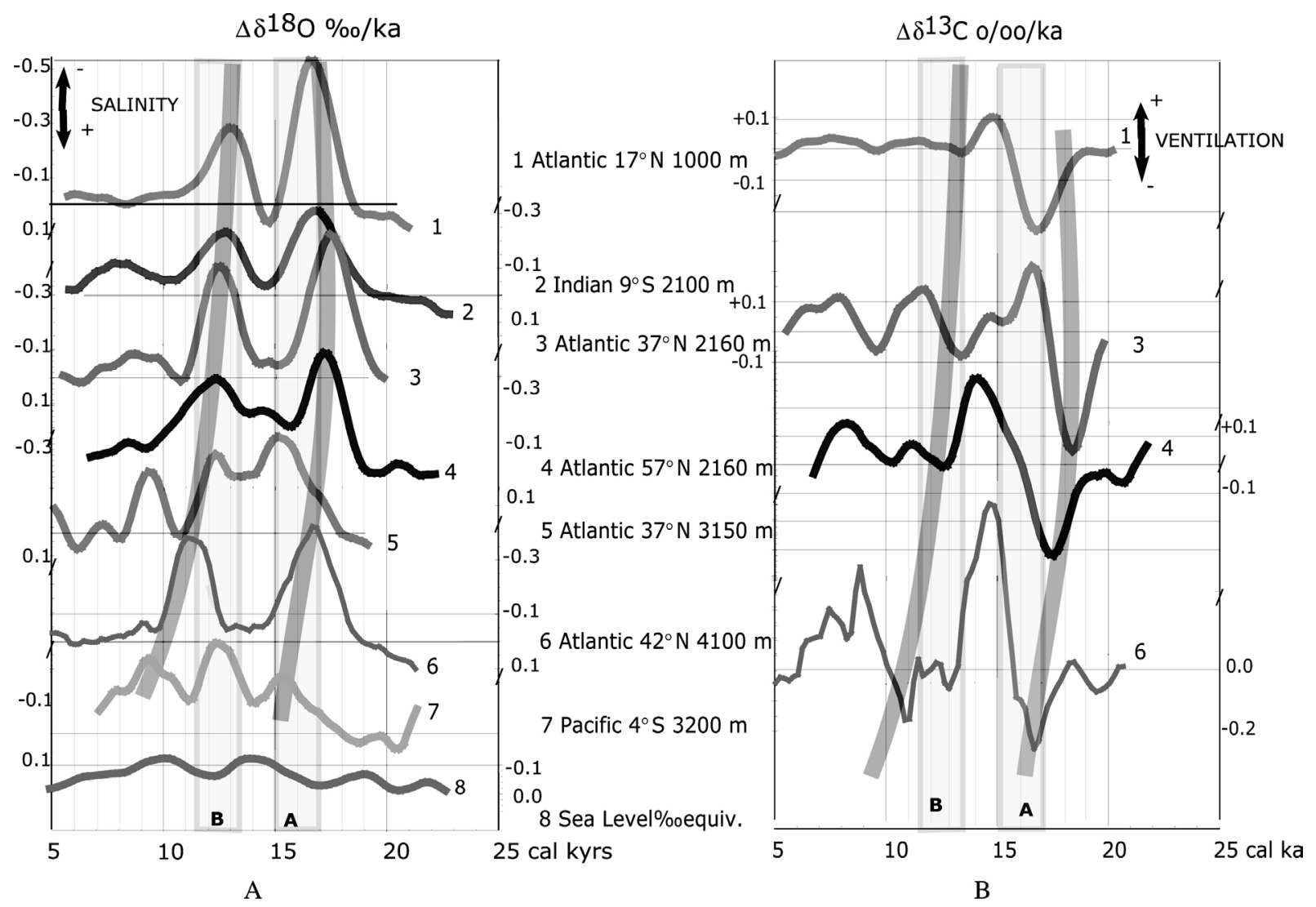

Fig. 2. (A) Benthic foraminifera $\partial \delta^{18} \mathrm{O} / \partial t$ for each core versus age (cal ka); (B) benthic foraminifera $\partial \delta^{13} \mathrm{C} / \partial t$ for each core versus age (cal ka) (see section Methods).

Fig. 2. (A) $\partial \delta^{18} \mathrm{O} / \partial t$ des foraminifères benthiques pour chaque carotte en fonction de l'âge (cal ka); (B) $\partial \delta^{13} \mathrm{C} / \partial t$ des foraminifères benthiques (voir $§$ Méthodes).

action to H1, and two others, one about in phase with YD, thus in phase with the intermediate water signal, the second one about $1.5 \mathrm{ka}$ later, which could be the delayed response to YD seen in the deeper Atlantic core CH69-K09.

The $\delta^{13} \mathrm{C}$ record of benthic foraminifera varied in phase with the $\delta^{18} \mathrm{O}$, reflecting large changes in deep-water ventilation (Fig. 2B). In the North Atlantic Ocean, the $\delta^{13} \mathrm{C}$ signal linked to the $\mathrm{H} 1$ event exhibits the same structure as that of the $\partial \delta^{18} \mathrm{O} / \partial t$ signal, with small differences in timing. A drastic lowering of the $\delta^{13} \mathrm{C}$ parallels the $\delta^{18} \mathrm{O}$ decrease. In the shallow core CHO288-54, the $\delta^{13} \mathrm{C}$ drop marks also the end of the highly ventilated glacial period. The same trend was observed in western Atlantic core M35003-4 at 1300 $\mathrm{m}$ water depth [42]. We do not present here the $\delta^{13} \mathrm{C}$ benthic record of the Indian Ocean core MD98-2165, where an increase in $\delta^{13} \mathrm{C}$ is observed during $\mathrm{H} 1$ and YD converging with Atlantic values for cores at the same depth $(2000 \mathrm{~m})$. Mean ventilation in that area is much lower than the Atlantic during the deglaciation. This result confirms thus our hypothesis of an increased intermediate water circulation for these periods [41].

As for $\partial \delta^{18} \mathrm{O} / \partial t$, the $\delta^{13} \mathrm{C}$ variations affect the deeper North Atlantic with a long delay of $\sim 1.5 \mathrm{ka}$.

During the second event, linked to $\mathrm{YD}$, the $\delta^{13} \mathrm{C}$ record of benthic foraminifera also shows a significant drop of ventilation at all water depths in the Atlantic Ocean. The signal is however less well defined, not visible in the shallowest core (1000 m), and early (?) in central Atlantic cores from 2100 and 4100 m (Fig. 2). 


\section{Palaeoceanographic implications}

Our analysis clearly shows the signature of two large amplitude decreases in $\delta^{18} \mathrm{O}$, affecting first the shallow and intermediate waters from the Atlantic and Indian Ocean, before being recorded in the deep Atlantic and Pacific oceans. Such a result has been recently emphasized by Skinner and Shackleton [34], based on a similar comparison between the Iberian margin record and the Pacific ocean core TR 163-31B. They found an overall delay of $3.9 \mathrm{ka}$ between the records of the last glacial termination. The 1.5 -ka difference that we observe between the same records by following separately the termination individual events is in better agreement with the time constant of the oceanic circulation during the deglaciation [9].

We have reported in Fig. 2, with the same scale, the derivative signal for the sea-level $\delta^{18} \mathrm{O}$ equivalent. Its amplitude is too small to have any significance in the present discussion. The temperature component in the foraminiferal $\delta^{18} \mathrm{O}$ signal in the Iberian margin core MD99-2334 [35], at the location of core MD95-2042, drops during the isotopic transitions, inducing a positive foraminiferal $\delta^{18} \mathrm{O}$ shift of +0.5 to $+1 \%$, thus in the opposite direction of the measured changes. The temperature shift tends therefore to partly compensate the water $\delta^{18} \mathrm{O}$ change, and to decrease its effect on foraminifera $\delta^{18} \mathrm{O}$. Similarly, deep-water temperature increases at the end of both isotopic events, opposing in part the effect of water $\delta^{18} \mathrm{O}$ increase. Thus, as a working hypothesis, we may consider that $\partial \delta^{18} \mathrm{O} / \partial t$ reflects for all the North Atlantic cores the temporal changes in seawater $\delta^{18} \mathrm{O}$ at the location of each core, with the amplitude reduced compared to the true changes. Conservatively admitting that Indian and $\mathrm{Pa}-$ cific intermediate and deep-water temperature did not change significantly, or changed in the same direction as Atlantic waters, each event must correspond to a large shift in ocean-water $\delta^{18} \mathrm{O}$, which can not be explained by sea-level changes (Fig. 2). The only hypothesis we see which may explain such amplitude is the injection of low $\delta^{18} \mathrm{O}$ water brines $[7,41]$ into intermediate oceanic waters during both $\mathrm{H} 1$ and YD. Brine formation probably occurred during the whole glaciation when ice sheets presented a large interface with the ocean. However, when open convection was active this efficient mode of deep-water formation masked the brine signal, which was largely diluted and not vis- ible. The brine signal emerged only at times of low meridional overturning [24]. However, the freezing of coastal seawater (and salt rejection) below cold ice shelves, at the origin of brine formation in the modern ocean [7], had probably greatly increased during surging phases of Heinrich events. The $\partial \delta^{18} \mathrm{O} / \partial t$ signal may then also represent periods of acceleration of brine-generated water injection in the intermediate waters of the different ocean basins.

Our results show therefore that:

- the isotopic events marked the penetration of low $\delta^{18} \mathrm{O}$ water (brine signature) through active intermediate water circulation, with no detectable delay between Atlantic and Indian oceans, and no large attenuation of the signal. This water is poorly ventilated, probably because the preformed deep water was itself poorly ventilated [12,39];

- for H1, the transmission of the signal was fast in the shallow and intermediate waters (Atlantic to Indian), but progressive, and with significant attenuation within deep waters (Atlantic to Pacific). We observe during YD the same rapid intermediate water transmission, and slow deep-water transmission (at least for the 4100-m water-depth Atlantic core). The ocean circulation carrying the signal during $\mathrm{H} 1$ and YD was therefore well decoupled above about 2000-m water depth and below. The evolution appears more complex between these depths, for the $3100 \mathrm{~m}$ depth cores. Both Atlantic and Pacific records show a two-peak response, as if part of the signal penetrated fast (linking these waters with the intermediate water system), and part slowly, linking these waters with the deep-water system.

A transmission of the signal between Atlantic, Indian and Pacific Oceans much faster than the present 1-2-ka delay must involve an active intermediate water formation in the North Atlantic, maybe relayed in the Southern Ocean (Glacial AAIW like), and bottom water formation around Antarctica. Our results do not support therefore the reality of a sluggish ocean usually invoked to explain the low $\delta^{13} \mathrm{C}$ signal in deep waters $[11,30]$, because such a slow circulation would be unable to transmit rapidly the $\delta^{18} \mathrm{O}$ signal brought by glacial meltwater. After $[7,12,39]$, we interpret the decrease in $\delta^{13} \mathrm{C}$ as due to the decrease in ventila- 
tion of the newly formed intermediate and deep waters enriched in brines, in the absence of open ocean convection.

However, we still have to explore several problems:

(1) why do ventilation-independent tracers as ${ }^{231} \mathrm{~Pa} /$ ${ }^{230} \mathrm{Th}$ indicate an interruption of the Atlantic Meridional overturning during the $\mathrm{H} 1$ event $[13,25]$, while we interpret our data as an increased separation between two cells of active circulation, one shallow and one deep? This question must be explored using model simulations of the ${ }^{231} \mathrm{~Pa}$ distribution following [23], but with a coupled ocean-atmosphere general circulation model able to correctly simulate the geochemistry of these tracers and the interactions between the various Atlantic water masses during a meltwater injection in the northern North Atlantic;

(2) why did the type of circulation seen during H1 re-establish in part during YD, after a period of modern-like circulation, and what is the origin of that low $\delta^{18} \mathrm{O}$ isotopic event? By contrast with Heinrich events, there are no known large meltwater anomalies in the high latitudes of the North Atlantic Ocean during YD [10]. Yet the $\partial \delta^{18} \mathrm{O} / \partial t$ event is seen at all depths. It has to come from somewhere.

\section{Conclusion}

We have demonstrated the occurrence of discrete events of brine water injection in the different intermediate oceanic water masses during the last deglaciation, using the time derivative of benthic foraminifera $\delta^{18} \mathrm{O}$ records of North Atlantic, Indian and Pacific Ocean cores. Two events are seen throughout, directly associated with the $\mathrm{H} 1$ ice surge that terminates the Last Glacial Period and with the YD. Both events are associated with a significant decrease in water ventilation. The signature of these events is transferred within a few hundred years to intermediate waters of the North Atlantic and Indian Oceans, but invasion of deeper waters (3000 to $4000 \mathrm{~m}$ ) takes about $1.5 \mathrm{ka}$, both in the Atlantic and Pacific Ocean. This corresponds to the strong isolation of the deep-water system observed during the Last Glacial period, which is apparently completely destroyed only after $10 \mathrm{cal} \mathrm{ka}$.

\section{Acknowledgements}

This study uses giant CALYPSO sediment cores collected during the IMAGES (International Marine Global Change Study) cruises of the R.S. Marion Dufresne under the authority of the 'Institut polaire français Paul-Émile-Victor' (IPEV) and the direction of Yvon Balut and the different chief scientists. Analyses done in LSCE with support from CNRS, CEA, PNEDC and EEC projects POP and CESOP.

\section{References}

[1] E. Bard, M. Arnold, J. Maurice, J. Duprat, J. Moyes, J.-C. Duplessy, Retreat velocity of the North Atlantic polar front during the last deglaciation determined by ${ }^{14} \mathrm{C}$ accelerator mass spectrometry, Nature 328 (1987) 791-794.

[2] G. Bond, H. Heinrich, W. Broecker, L. Labeyrie, J. McManus, J. Andrews, S. Huon, R. Jantschik, C. Clasen, C. Simet, K. Tedesco, M. Klas, G. Bonani, Evidence for massive discharges of icebergs into the glacial north Atlantic, Nature 360 (1992) 245-249.

[3] G. Bond, W. Broecker, S. Johnsen, J. McManus, L. Labeyrie, J. Jouzel, G. Bonani, Correlations between climate records from North Atlantic sediments and Greenland ice, Nature 365 (1993) 143-147.

[4] W.S. Broecker, M. Andrée, W. Wolfli, H. Oeshger, G. Bonani, J. Kennett, D. Peteet, The chronology of the last deglaciation: implications to the cause of the Younger Dryas event, Paleoceanography 3 (1988) 1-19.

[5] E. Cortijo, L. Labeyrie, L. Vidal, M. Vautravers, M.R. Chapman, J.-C. Duplessy, M. Elliot, M. Arnold, J.-L. Turon, G.A. Auffret, Changes in sea-surface hydrology associated with Heinrich event 4 in the North Atlantic Ocean between $40^{\circ}$ and $60^{\circ} \mathrm{N}$, Earth Phys. Sci. Lett. 146 (1997) 29-45.

[6] E. Cortijo, J.-C. Duplessy, L. Labeyrie, J. Duprat, D. Paillard, Heinrich events: hydrological impact, C. R. Geoscience 337 (2005).

[7] T.M. Dokken, E. Jansen, Rapid changes in the mechanism of ocean convection during the last glacial period, Nature 401 (1999) 458-461.

[8] J.-C. Duplessy, L. Labeyrie, M. Arnold, M. Paterne, J. Duprat, T.C.E. van Weering, Changes in surface salinity of the North Atlantic Ocean during the last deglaciation, Nature 358 (1992) 485-487.

[9] J.-C. Duplessy, E. Bard, M. Arnold, N.J. Shackleton, J. Duprat, L. Labeyrie, How fast did the ocean-atmosphere system run during the last deglaciation?, Earth Planet. Sci. Lett. 103 (1991) 27-40.

[10] J.-C. Duplessy, L. Labeyrie, M. Paterne, North Atlantic seasurface conditions during the Younger Dryas cold event, in: J.T. Andrews, W.E.N. Austin, H. Bergsten, A.E. Jennings (Eds.), The Late Glacial paleoceanography of the North Atlantic margins, Geol. Soc. Spec. Publ. 111 (1996) 167-175. 
[11] J.-C. Duplessy, N.J. Shackleton, R.G. Fairbanks, L.D. Labeyrie, D. Oppo, N. Kallel, Deep water source variations during the last climatic cycle and their impact on the global deep water circulation, Paleoceanography 3 (1988) 343-360.

[12] M. Elliot, L. Labeyrie, J.-C. Duplessy, Changes in North Atlantic deep-water formation associated with the DansgaardOeschger temperature oscillations (10-60 ka), Quat. Sci. Rev. 21 (2002) 1153-1165.

[13] J.-M. Gherardi, L. Labeyrie, J.F. McManus, R. François, L.C. Skinner, E. Cortijo, Evidence from the North Eastern Atlantic Basin for variability of the meridional overturning circulation through the Last Deglaciation, submitted for publication.

[14] P.M. Grootes, M. Stuiver, J.W.C. White, S. Johnsen, J. Jouzel, Comparison of oxygen isotopes records from the GISP 2 and GRIP Greenland ice cores, Nature 466 (1993) 552-554.

[15] N. Kallel, L.D. Labeyrie, A. Juillet-Leclerc, J.-C. Duplessy, A deep hydrological front between intermediate and deepwater masses in the glacial Indian Ocean, Nature 333 (1988) 651-655.

[16] G. Knorr, G. Lohmann, Southern Ocean origin for the resumption of Atlantic thermohaline circulation during deglaciation, Nature 424 (2003) 532-536.

[17] P. Kroopnick, Distribution of ${ }^{13} \mathrm{C}$ and $\Sigma \mathrm{CO}_{2}$ in the world oceans, Deep-Sea Res. 32 (1984) 57-77.

[18] L. Labeyrie, H. Leclaire, C. Waelbroeck, E. Cortijo, J.-C. Duplessy, L. Vidal, M. Elliot, B. Lecoat, G. Auffret, Temporal variability of the surface and deep waters of the North West Atlantic ocean at orbital and millenial scales, in: P. Clark, R.S. Webb, L.D. Keigwin (Eds.), Mechanisms of Global Climate Change at millenial time scales, AGU, Washington, 1999, pp. 77-98.

[19] L. Labeyrie, J. Cole, K. Alverson, T. Stocker, The history of climate dynamics in the Late Quaternary, in: R.B. Keith Alverson, Thomas Pedersen (Eds.), Paleoclimates, Global Change and the Future, in: IGBP series, Springer, Berlin, 2002, pp. 3362.

[20] L. Labeyrie, L. Vidal, E. Cortijo, M. Paterne, M. Arnold, J.-C. Duplessy, M. Vautravers, M. Labracherie, J. Duprat, J.-L. Turon, F. Grousset, T. van Weering, Surface and deep hydrology of the northern Atlantic Ocean during the last 150,000 years, Phil. Trans. R. Soc. Lond. 348 (1995) 255-264.

[21] K. Lambeck, J. Chappell, Sea level change through the Last Glacial Cycle, Science 292 (2001) 679-686.

[22] C. Levi, Étude des variations climatiques de la zone IndoPacifique : rôle des basses latitudes dans la variabilité millénaire du climat, thèse, université Paris-11-Orsay, France, 2003.

[23] O. Marchal, R. François, T.F. Stocker, F. Joos, Ocean thermohaline circulation and sedimentary ${ }^{231} \mathrm{~Pa} /{ }^{230} \mathrm{Th}$ ratio, Paleoceanography 15 (2000) 625-641.

[24] J. Marshall, G.K.C. Clarke, Modeling North American frshwater runoff through the last glacial cycle, Quat. Res. 52 (1999) 300-315.

[25] J. McManus, R. Francois, J.-M. Gherardi, L.D. Keigwin, S. Brown-Leger, Collapse and rapid resumption of Atlantic meridional circulation linked to deglacial climate changes, Nature 428 (2004) 834-837.

[26] D.R. Ostermann, W.B. Curry, Calibration of stable isotopic data: an enriched $\delta^{18} \mathrm{O}$ standard used for source gas mixing detection and correction, Paleoceanography 15 (2000) 353360.

[27] D. Paillard, L. Labeyrie, Role of the thermohaline circulation in the abrupt warming after Heinrich events, Nature 372 (1994) 162-164.

[28] D. Paillard, L. Labeyrie, P. Yiou, Macintosh program performs time-series analysis, EOS Trans. AGU 77 (1996) 379.

[29] D. Paillard, E. Cortijo, A Simulation of the Atlantic meridional circulation during Heinrich event 4 using reconstructed sea surface temperatures and salinities, Paleoceanography 14 (1999) 716-724.

[30] M. Sarnthein, K. Winn, S.J.A. Jung, J.-C. Duplessy, L.D. Labeyrie, H. Erlenkeuser, G. Ganssen, Changes in east Atlantic deep water circulation over the last 30000 years: Eight time slice reconstructions, Paleoceanography 9 (1994) 209-267.

[31] E. Savitzky, J.E. Golay, Smoothing and differentiation of data by simplified least squares procedure, Anal. Chem. 36 (1964) $1627-1639$.

[32] N.J. Shackleton, M.A. Hall, J. Line, C. Shuxi, Carbon isotope data in core V19-30 confirm reduced carbon dioxide concentration in the ice age atmosphere, Nature 306 (1983) 319322.

[33] N.J. Shackleton, M.A. Hall, E. Vincent, Phase relationships between millenial-scale events 64000-24000 years ago, Paleoceanography 15 (6) (2000) 565-569.

[34] L.C. Skinner, N.J. Shackleton, An Atlantic lead over Pacific deep-water change across Termination I: implications for the application of the marine isotope stage stratigraphy, Quat. Sci. Rev. 24 (2005) 571-580.

[35] L.C. Skinner, N.J. Shackleton, H. Elderfield, Millennial-scale variability of deep-water temperature and $\delta^{18} \mathrm{O}_{\mathrm{dw}}$ indicating deep-water source variations in the Northeast Atlantic, 0-34 cal. ka BP, Geochem. Geophys. Geosyst. 4 (2003) 1098; 10.1029/2003GC000585.

[36] T. Stocker, D.G. Wright, Rapid transitions of the ocean's deep circulation induced by changes in surface water fluxes, Nature 351 (1991) 729-732

[37] H. Stommel, Thermohaline convection with two stable regimes of flow, Tellus 13 (1961) 224-230.

[38] M. Stuiver, Reimer P.J., Extended ${ }^{14} \mathrm{C}$ data base and revised CALIB $3.0{ }^{14} \mathrm{C}$ age calibration program, Radiocarbon 35 (1993) 215-230.

[39] L. Vidal, L. Labeyrie, E. Cortijo, M. Arnold, J.-C. Duplessy, E. Michel, S. Becqué, T.C.E. van Weering, Evidence for changes in the North Atlantic deep water linked to meltwater surges during the Heinrich events, Earth Planet. Sci. Lett. 146 (1997) 13-26.

[40] C. Waelbroeck, J.-C. Duplessy, E. Michel, L. Labeyrie, D. Paillard, J. Duprat, The timing of the last deglaciation in North Atlantic climate records, Nature 412 (2001) 724-727.

[41] C. Waelbroeck, C. Levi, J.-C. Duplessy, L. Labeyrie, E. Michel, E. Cortijo, F. Bassinot, F. Guichard, Distant origin of circulation changes in the Indian Ocean during the last deglaciation, Earth Planet. Sci. Lett., submitted for publication.

[42] R. Zahn, A. Stuber, Suborbital intermediate water variability inferred from paired benthic foraminiferal $\mathrm{Cd} / \mathrm{Ca}$ and $\delta^{13} \mathrm{C}$ in the tropical West Atlantic and linking with North Atlantic climates, Earth Planet. Sci. Lett. 200 (2002) 191-205. 